\title{
Ewenki Chinese
}

National Cancer Institute

\section{Source}

National Cancer Institute. Ewenki Chinese. NCI Thesaurus. Code C158199.

A Chinese person from the Ewenki ethnic group. 